\title{
Plant age effects on soil infiltration rate during early plant establishment
}

\author{
A. K. LEUNG*, D. BOLDRIN*†, T. LIANG*, Z. Y. WU*, V. KAMCHOOM‡ and A. G. BENGOUGH*†
}

\begin{abstract}
Infiltration rate affects slope stability by determining the rate of water transport to potential failure planes. This note considers the influences of vegetation (grass and willow) establishment and root growth dynamics on infiltration rate, as related to establishing vegetation on bioengineered slopes. Soil columns of silty sand with and without vegetation were tested by constant-head infiltration tests at 2, 4, 6 and 8 weeks after planting. Infiltration rate increased linearly with plant age and below-ground traits including root biomass and root length density. Infiltration rate for willow-rooted soil was an order of magnitude higher than for fallow soil. The plant age effect was more prominent for willow, which grew faster and with thicker roots than the grass. Illustrative seepage analysis suggests that ignoring the plant age effects could underestimate wetting front advancement to greater depths during rainfall, and underestimate suction recovery at shallow depths during internal drainage.
\end{abstract}

KEYWORDS: partial saturation; permeability; seepage; suction; vegetation; water flow

\section{INTRODUCTION}

Soil infiltration rate plays a key role in slope hydrology and stability. It is one of the most important soil parameters that affects prediction of slope failure mechanism, especially when soil-plant interaction in shallow soil is taken into account (Nyambayo \& Potts, 2010; Sidle \& Bogaard, 2016; Tsiampousi et al., 2017). Plant roots permeated into the soil matrix could modify the soil structure (Scholl et al., 2014; $\mathrm{Ng}$ et al., 2016) and hence affect the infiltration rate due to root growth and penetration (Ghestem et al., 2011). Effects of roots on soil infiltrability have often shown contrasting results. Studies that focus on relatively young plants found slowing of infiltration (Gish \& Jury, 1983; Leung et al., 2015; Jotisankasa \& Sirirattanachat, 2017) presumably due to root occupancy of soil pore space, which blocks water flow paths (Scholl et al., 2014; $\mathrm{Ng}$ et al., 2016). In contrast, increased infiltration rate is more often reported in mature plants (van Noordwijk et al., 1991; Mitchell et al., 1995; $\mathrm{Ng}$ et al., 2017), and is attributable to the formation of $(a)$ root channel related macropores associated with root decay (Ghestem et al., 2011) or (b) desiccation cracks upon drying of medium- to high-plasticity clay (Zhan et al., 2007; Jotisankasa \& Sirirattanachat, 2017; Song et al., 2017). The existing research often considered plant effects only at one particular plant age. Although limited studies have reported infiltration data at different plant ages (Table 1), the role of root growth dynamics is generally ignored, leaving gaps in the understanding of its effects on infiltration.

This note quantifies effects of plant age on soil infiltration rate and the associated impact on soil hydrology for two

Manuscript received 31 July 2017; revised manuscript accepted 5 October 2017. Published online ahead of print 10 November 2017. Discussion on this paper closes on 1 December 2018, for further details see $p$. ii.

Published with permission by the ICE under the CC-BY 4.0 license. (http://creativecommons.org/licenses/by/4.0/)

* Discipline of Civil Engineering, School of Science and Engineering, University of Dundee, Dundee, UK.

$\dagger$ The James Hutton Institute, Invergowrie, Dundee, UK.

t Department of Civil and Environmental Engineering, Hong Kong

University of Science and Technology, Hong Kong SAR. contrasting species (herbaceous and woody species). Particular attention is paid to the soil-plant interaction during early plant establishment, which represents a critical period for slope stabilisation using soil bio-engineering methods (Schmidt et al., 2001; Stokes et al., 2014; Sidle \& Bogaard, 2016).

\section{METHODS \\ Selected plant species}

Two species were tested, Salix viminalis tora (willow) and Lolium perenne $\times$ Festuca pratensis hybrid (Festulolium grass), which represent two plant functional groups that have contrasting root systems. The willow is a fast-growing species, and a common candidate for slope stabilisation in multiple soil bio-engineering projects (Steele et al., 2004; Mickovski et al., 2009; Wu et al., 2014). The grass was bred by the Welsh Plant Breeding Station in the 1970s, and has been recently selected for flood mitigation purposes (Macleod et al., 2013).

\section{Soil type and preparation of soil columns}

The soil tested was collected from Bullionfield, The James Hutton Institute, Dundee, UK. It was a silty sand, which comprises $71 \%$ sand, $19 \%$ silt and $10 \%$ clay, and has field capacity of $0.27 \mathrm{~g} / \mathrm{g}$. The soil (sieved $<2 \mathrm{~mm}$; optimum water content of $0.18 \mathrm{~g} / \mathrm{g}$ ) was compacted into ten layers in a column of $50 \mathrm{~mm}$ dia. and $450 \mathrm{~mm}$ high. The targeted dry density was $1400 \mathrm{~kg} / \mathrm{m}^{3}$. At the bottom of each column, a $20 \mathrm{~mm}$ thick layer of pea gravel was placed to facilitate drainage during testing.

A pre-germinated seed of grass was sown at $5 \mathrm{~mm}$ depth in each soil column. For growing willow, branch cuttings were used - collected in early spring when the willows were dormant. One-third of a $100 \mathrm{~mm}$ long branch $(12 \cdot 0 \pm 0 \cdot 1 \mathrm{~mm}$ diameter; mean \pm standard error) was inserted into each soil column. In total, 27 columns were prepared ( 12 for the grass, 12 for the willow and three for fallow soil as control). All columns were placed in a growing area, where the lighting and temperature were controlled. A data logger (EL-USB-2; Lascar electronics, UK) was used to monitor temperature during day/night cycles (daytime $-16 \mathrm{~h}$ of light; $27 \cdot 3 \pm 0 \cdot 4^{\circ} \mathrm{C} ;$ night $-8 \mathrm{~h}$ of dark; $22 \cdot 2 \pm 0 \cdot 1^{\circ} \mathrm{C}$; mean \pm standard error). Columns were irrigated every 2 days 
Table 1. Studies reporting effects of plant age on infiltration rate or saturated hydraulic conductivity

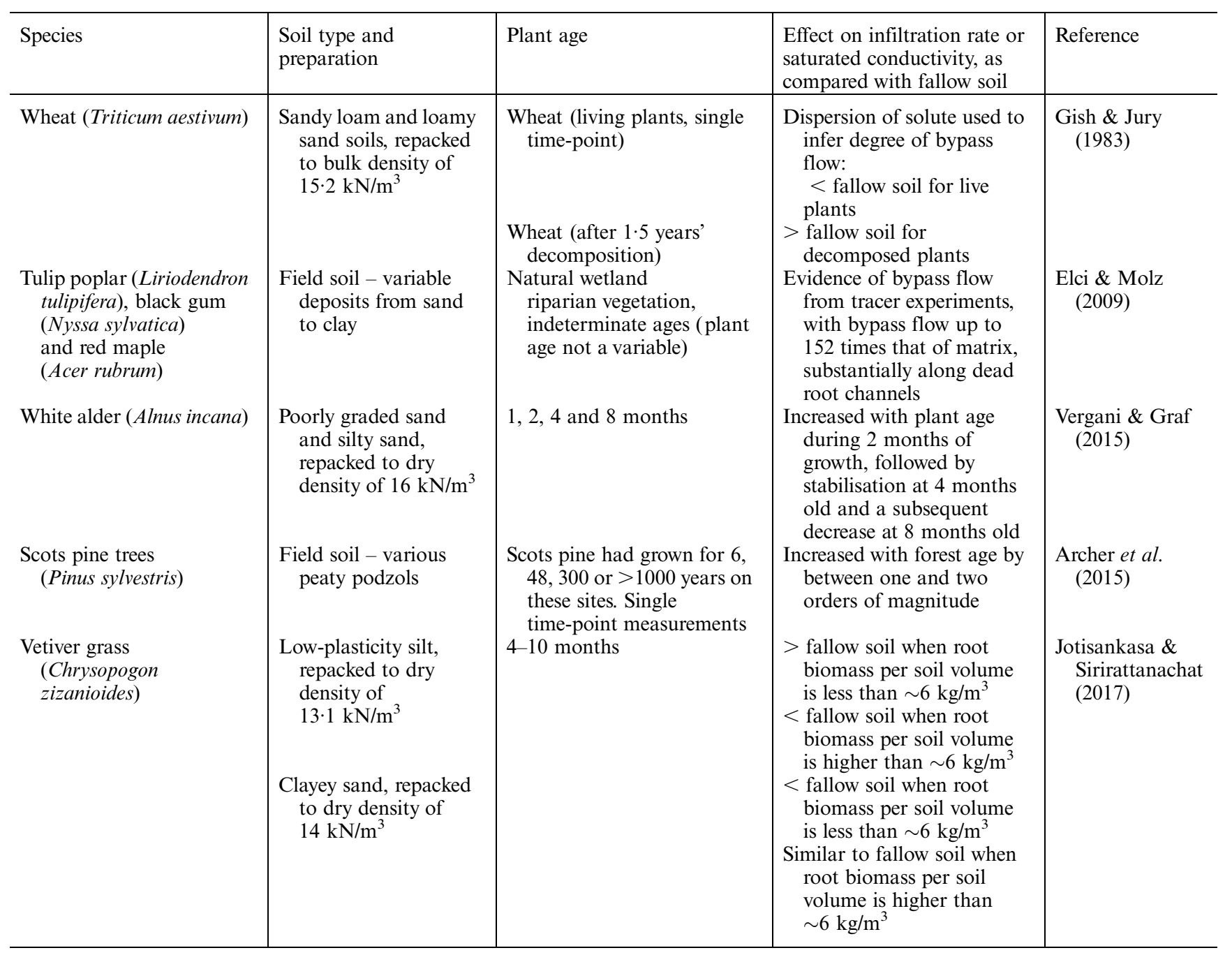

and the amount of water added was used to adjust soil water content to field capacity.

\section{Test procedures}

Three replicated soil columns were taken for infiltration testing after growing for 2, 4, 6 and 8 weeks. Before testing, each column was saturated with water for $24 \mathrm{~h}$. A Mariotte bottle was then connected near the top of the column for applying a constant ponding head of $20 \mathrm{~mm}$ at the soil surface, while allowing free drainage at the column base. The hydraulic gradient across each soil column was thus controlled at $1 \cdot 04$. The rate of change of water volume in the Mariotte bottle was recorded continuously until a steadystate condition was reached. Steady-state infiltration rate was obtained by dividing the rate of change of water volume by the column sectional area.

To measure the plant traits, root biomass and root length density (RLD), 12 additional columns were prepared in parallel for each plant type (three replications for each plant age). Root samples were excavated and washed from the soil, with extra care taken not to discard finer roots. The measurements of the two plant traits followed the procedures reported in Boldrin et al. (2017) and Liang et al. (2017).

\section{Statistical analysis}

GenStat 17th edition (VSN International) and SigmaPlot13 (Systat Software Inc.) were used for statistical analysis. Significant differences were assessed with one-way Anova (analysis of variance), followed by post hoc Tukey's test. Correlations were tested using Spearman's rank correlation analysis and regression analysis. Results were considered statistically significant when $p$-value $\leq 0 \cdot 05$.

\section{RESULTS AND DISCUSSION}

Figures 1 and 2 highlight contrasting patterns of root growth exhibited by the grass and the willow. It can be seen in Fig. 1 that the root system of grass during the early-stage development (i.e. first 4 weeks) was mainly constituted by very thin roots (i.e. dia. $<0 \cdot 1 \mathrm{~mm}$ ), which accounted for about $40 \%$ of total root length. Grass roots with a diameter larger than $0.5 \mathrm{~mm}$ represent only $3 \%$ of total root length. On the contrary, for 2 week old willow (Fig. 2), very thin roots represent less than $20 \%$ of total root length. More than $30 \%$ of total root length is found in the diameter classes larger than $0.5 \mathrm{~mm}$ (i.e. ten-fold higher than in the grass).

The infiltration rate for the vegetated soil was generally faster than for the fallow soil, regardless of plant type and age (Fig. 3, Tables 2 and 3: except for the 2 week old grass). Root growth and penetration therefore might have created sufficient macro-pore space in the soil matrix to enhance infiltration. For both species, infiltration was linearly correlated with plant age ( $p$-value $<0.001)$. Infiltration rate for the 8 week old willow and grass increased by four and six times, respectively, as compared with the 2 week old plants. Infiltration rate was related to root biomass (Fig. 4(a)) and 


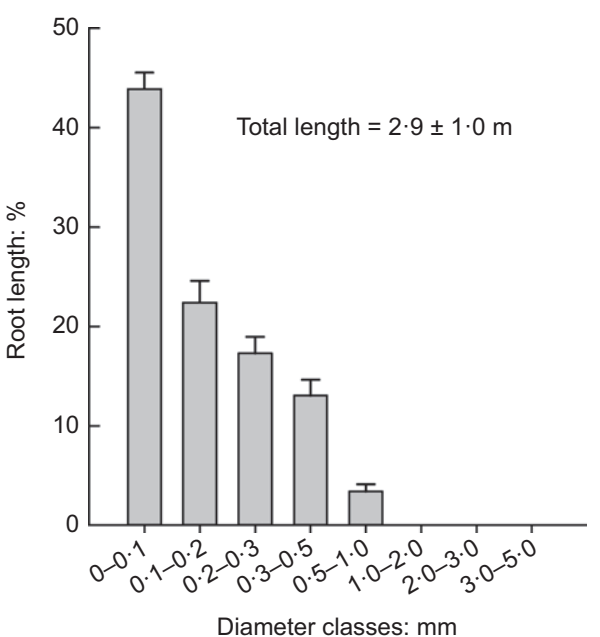

(a)

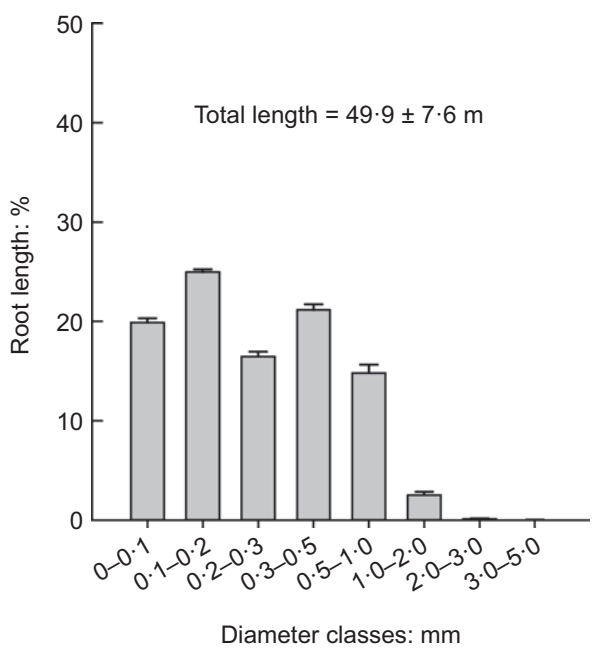

(c)

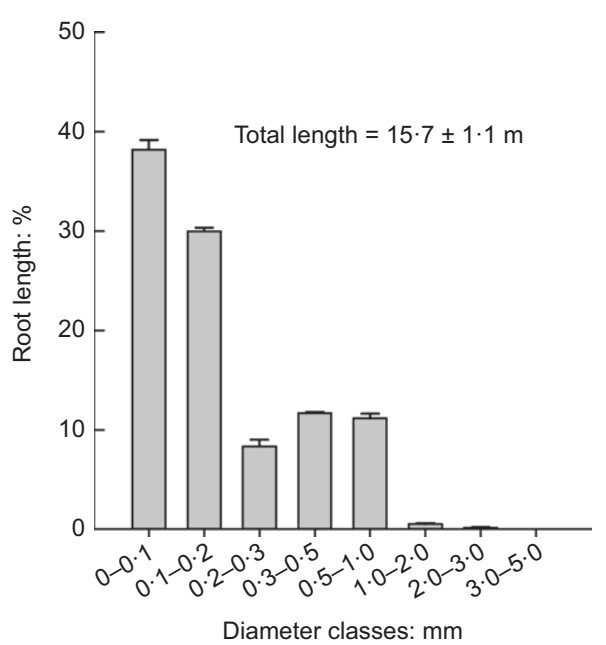

(b)

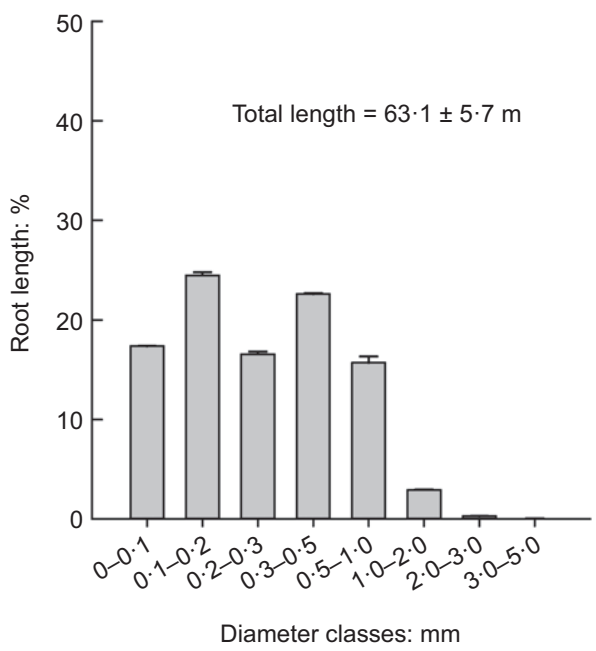

(d)

Fig. 1. Percentage of grass root length in each diameter class between <0.1 and $5 \cdot 0$ mm at: (a) 2 weeks; (b) 4 weeks; (c) 6 weeks; (d) 8 weeks. Note that the lower boundary of diameter class is included in the class whereas the upper boundary is not. Values of total root length are given in the graphs. Mean values are reported \pm standard error of mean $(n=3)$

RLD (Fig. 4(b)), as these two traits also increased with age (Tables 2 and 3 ). These relations appear to be species specific. This is because both root biomass and RLD are related to other traits such as root length in each diameter class (Figs 1 and 2), which could at the same time affect these relations.

The faster infiltration rates in willow, as compared with grass at any age, may be due to the faster growth rate of willow and its greater quantity of larger roots $(>0.5 \mathrm{~mm})$ (Figs 1 and 2, and Table 2). Bodner et al. (2014) showed that coarser root systems would more prominently increase macro-porosity, while species with dense, finer root systems, such as grass, increase the heterogeneity of soil pore space and increase micro-pore volume. Indeed, very fine roots could permeate and so decrease large micro-pore and fine macro-pore $(2 \cdot 5-500 \mu \mathrm{m})$ volume (Scholl et al., 2014). In the present authors' experiments, the very small grass roots may therefore have blocked soil pores and slowed infiltration, whereas larger grass and willow roots may have generated preferential pathways in the soil for water flow.

\section{ENGINEERING IMPLICATIONS}

Illustrative transient seepage analysis was conducted to investigate the significance of plant age effects in soil bio-engineering practice. The finite element, Hydrus 1-D (Šimůnek et al., 2013), was used. One-dimensional (1D) seepage in soil was modelled by the Darcy-Richards equation. Two soil hydraulic properties, the soil water retention curve and soil hydraulic conductivity function, are needed to solve the equation. The soil water retention curve of the silty sand was measured by Liang et al. (2017) and van Genuchten (1980) model parameters fitted to the data (Table 4). The soil hydraulic conductivity function was estimated using the Muleam-van Genuchten equation (van Genuchten, 1980). The saturated hydraulic conductivity for each case was obtained by dividing the measured steady-state infiltration rate by the hydraulic gradient of 1.04 controlled in all column tests, assuming Darcy's law.

A 1D, 2 m deep soil column, with and without vegetation, was simulated. For vegetated cases, two soil domains were created. Depending on the rooting depth, the top domain represents soil permeated with roots, while the bottom domain represents bare soil. For illustrative purposes, the root growth model proposed by Šimůnek \& Suarez (1993) was adopted to estimate the rooting depth at different ages

$$
L_{\mathrm{R}}(t)=\frac{L_{0}}{L_{0}+\left(L_{\mathrm{m}}-L_{0}\right) \mathrm{e}^{(-g t)}} L_{\mathrm{m}}
$$




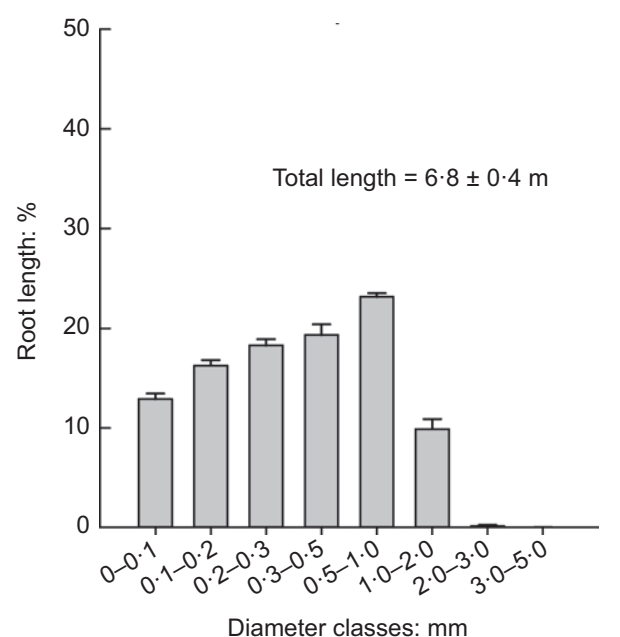

(a)

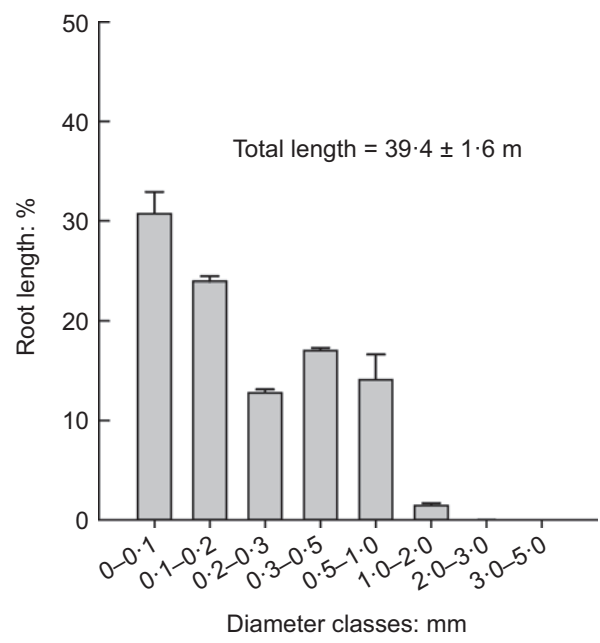

(c)

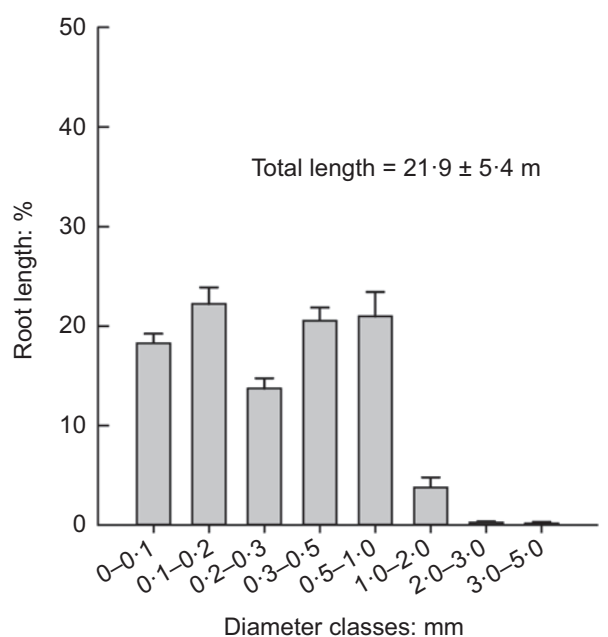

(b)

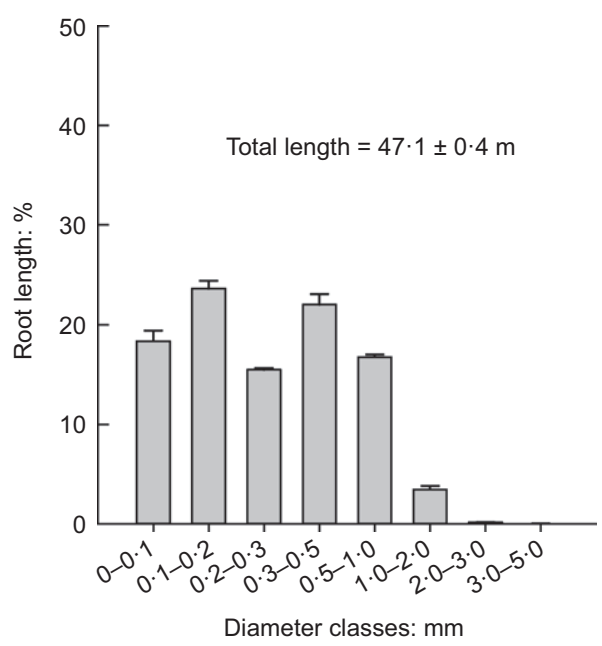

(d)

Fig. 2. Percentage of willow root length in each diameter class between <0・1 and 5.0 mm at: (a) 2 weeks; (b) 4 weeks; (c) 6 weeks; (d) 8 weeks. Note that the lower boundary of diameter class is included in the class whereas the upper boundary is not. Values of total root length are given in the graphs. Mean values are reported \pm standard error of mean $(n=3)$

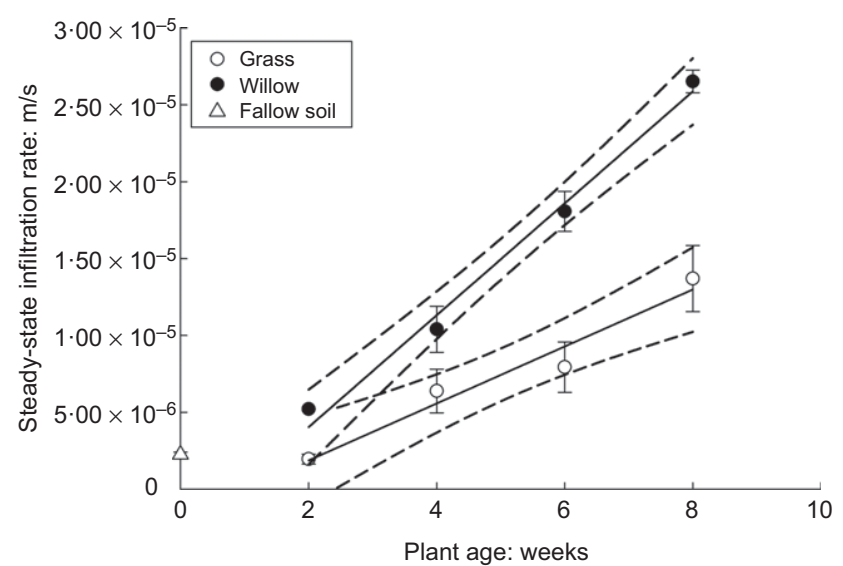

Fig. 3. Relationships between steady-state infiltration rate and the age of grass and willow. Mean values are reported \pm standard error of mean $(n=3)$. Linear regressions of all data points from all replicates are given in Table 3. Dashed lines represent $95 \%$ confidence bands. Spearman's rank correlation analysis between infiltration and plant age of all replications was performed for grass: $r=0.92$ and $P$-value $<0.001$, and willow: $r=0.97$ and $P$-value $<0.001$. Triangle on $y$-axis (open symbol) represents the mean value of infiltration recorded in fallow soil $\left(2.25 \times 10^{-6} \pm 1.53 \mathrm{~m} / \mathrm{s}\right)$ where $t$ is growing period; $L_{0}$ is initial rooting depth; $L_{\mathrm{m}}$ is the maximum rooting depth (assumed to be $1.5 \mathrm{~m}$ for willow, and $0.5 \mathrm{~m}$ for grass); and $\mathrm{g}$ is the root growth coefficient. The root growth coefficient is to control the non-linearity of the relationship between rooting depth and growth period. Based on the observed root depth at different plant age (Table 2) and the assumed maximum rooting depth, the root growth coefficient is found to be 0.4 and 0.8 week $^{-1}$ for the willow and the grass, respectively. Hence, rooting depth after 2, 4, 6 and 8 weeks' growth for the willow and the grass are known. At each plant age, the vegetated columns, and a fallow column as control, were subjected to the same rainfall intensity of $10 \mathrm{~mm} / \mathrm{d}$ for $2 \mathrm{~d}$ and then internal drainage for another $8 \mathrm{~d}$. Note that zero plant transpiration and zero canopy rainfall interception was assumed in all analyses (approximating winter conditions for the deciduous willow). All analyses considered a fixed groundwater table at $2 \mathrm{~m}$ depth and the initial distribution of suction was hydrostatic.

Figure 5 compares the effects of willow and grass on the distribution of suction (or negative pore-water pressure) after rainfall. Ignoring the plant effects on infiltration underestimated the wetting front advance and, importantly, overestimated the suction preserved at depth during rainfall. Because of increased drainage by plant roots, higher suction was preserved in the surface horizon. Grass roots showed similar trends to willow (Fig. 5(b)) but to a lesser extent, as 
Table 2. Summary of measurements (mean \pm standard error of mean) for both grass and willow

\begin{tabular}{|c|c|c|c|c|}
\hline Age: weeks & Infiltration rate: $\mathrm{m} / \mathrm{s}$ & Root depth: mm & Root biomass: $\mathrm{g}$ & Root length density: $\mathrm{cm} / \mathrm{cm}^{3}$ \\
\hline \multicolumn{5}{|l|}{ Grass } \\
\hline 2 & $1.96 \times 10^{-6} \pm 3.25 \times 10^{-7} \mathrm{a}$ & $173 \pm 0$ & $0 \cdot 012 \pm 0 \cdot 001 \mathrm{a}$ & $0 \cdot 82 \pm 0 \cdot 22 \mathrm{a}$ \\
\hline 4 & $6.39 \times 10^{-6} \pm 1.42 \times 10^{-6} \mathrm{ab}$ & $367 \pm 1$ & $0.065 \pm 0.005 b$ & $2 \cdot 19 \pm 0 \cdot 22 \mathrm{a}$ \\
\hline 6 & $7.93 \times 10^{-6} \pm 1.64 \times 10^{-6} \mathrm{ab}$ & $450 \pm 2$ & $0 \cdot 338 \pm 0 \cdot 010 \mathrm{c}$ & $5 \cdot 64 \pm 0 \cdot 86 b$ \\
\hline 8 & $1.37 \times 10^{-5} \pm 2 \cdot 16 \times 10^{-6} b$ & $450 \pm 3$ & $0 \cdot 461 \pm 0 \cdot 025 c$ & $7 \cdot 14 \pm 0 \cdot 64 b$ \\
\hline \multicolumn{5}{|c|}{ - } \\
\hline 2 & $5 \cdot 21 \times 10^{-6} \pm 2 \cdot 34 \times 10^{-9} a$ & $256 \pm 16$ & $0 \cdot 075 \pm 0 \cdot 005 \mathrm{a}$ & $2 \cdot 42 \pm 0 \cdot 80 \mathrm{a}$ \\
\hline 4 & $1.04 \times 10^{-5} \pm 1.50 \times 10^{-6} \mathrm{~b}$ & $450 \pm 0$ & $0 \cdot 154 \pm 0 \cdot 014 b$ & $3 \cdot 00 \pm 0 \cdot 67 \mathrm{ab}$ \\
\hline 6 & $1.81 \times 10^{-5} \pm 1.30 \times 10^{-6} \mathrm{c}$ & $450 \pm 0$ & $0 \cdot 352 \pm 0 \cdot 022 c$ & $4 \cdot 46 \pm 0 \cdot 18 \mathrm{ab}$ \\
\hline 8 & $2.65 \times 10^{-5} \pm 7 \cdot 35 \times 10^{-7} \mathrm{~d}$ & $450 \pm 0$ & $0 \cdot 552 \pm 0 \cdot 035 \mathrm{~d}$ & $5 \cdot 33 \pm 0 \cdot 05 b$ \\
\hline
\end{tabular}

Note: Letters indicate significant differences as tested using one-way Anova followed by post hoc Tukey's test (root biomass data for both species and infiltration rate data for willow were square root transformed in statistical analysis). Note that root depth was constrained to a maximum of $450 \mathrm{~mm}$, due to column dimensions

Table 3. Summary of the fitting coefficients ( $m$ and $y_{0} \pm$ standard error) and adjusted coefficient of determination $\left(R^{2}\right)$ for the linear relationships $\left(f=y_{0}+m \times x\right)$ given in Figs 3 and 4

\begin{tabular}{|c|c|c|c|c|}
\hline Relationship & Figure & $m$ & $y_{0}$ & Adj. $R^{2}$ \\
\hline \multicolumn{5}{|l|}{ Grass } \\
\hline Infiltration rate against age & 3 & $1.85 \times 10^{-6} \pm 3.28 \times 10^{-7}$ & $-1.83 \times 10^{-6} \pm 1.83 \times 10^{-6}$ & 0.76 \\
\hline Infiltration rate against root biomass & $4(\mathrm{a})$ & $2 \cdot 06 \times 10^{-5} \pm 6 \cdot 42 \times 10^{-6}$ & $2.99 \times 10^{-6} \pm 1.85 \times 10^{-6}$ & 0.76 \\
\hline Infiltration rate against RLD & $4(\mathrm{~b})$ & $1.53 \times 10^{-6} \pm 4 \cdot 26 \times 10^{-7}$ & $1.44 \times 10^{-6} \pm 2 \cdot 00 \times 10^{-6}$ & $0 \cdot 80$ \\
\hline \multicolumn{5}{|l|}{ Willow } \\
\hline Infiltration rate against age & 3 & $3.64 \times 10^{-6} \pm 2.75 \times 10^{-7}$ & $-3 \cdot 24 \times 10^{-6} \pm 1 \cdot 57 \times 10^{-6}$ & $0 \cdot 95$ \\
\hline Infiltration rate against root biomass & 4(b) & $4.34 \times 10^{-5} \pm 2.43 \times 10^{-6}$ & $2 \cdot 76 \times 10^{-6} \pm 8 \cdot 23 \times 10^{-7}$ & 0.99 \\
\hline Infiltration rate against RLD & 4(b) & $6.93 \times 10^{-6} \pm 6 \cdot 26 \times 10^{-7}$ & $-1 \cdot 13 \times 10^{-5} \pm 2 \cdot 49 \times 10^{-6}$ & 0.98 \\
\hline
\end{tabular}

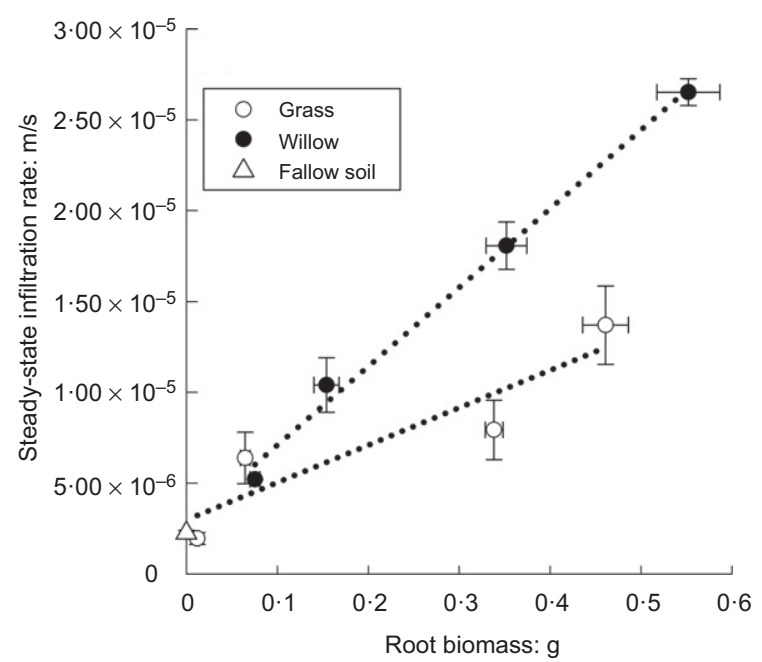

(a)

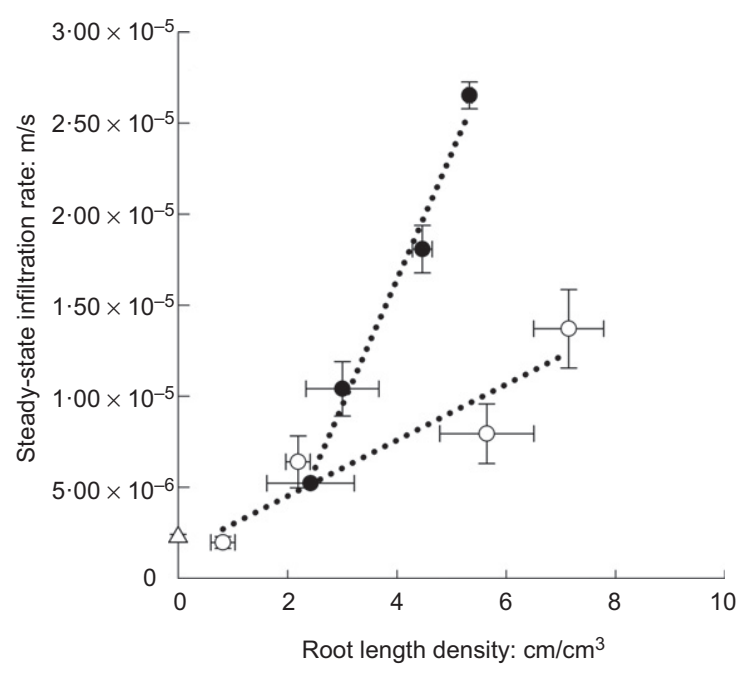

(b)

Fig. 4. (a) Relationships between steady-state infiltration and root biomass for grass and willow. (b) Relationships between steady-state infiltration and root length density for grass and willow. Mean values are reported \pm standard error of mean $(n=3)$. Dotted lines represent the trends in the relationships between infiltration and root traits (Table 3). Triangle on $y$-axis (open symbol) represents the mean value of infiltration recorded in fallow soil $\left(2.25 \times 10^{-6} \pm 1.53 \mathrm{~m} / \mathrm{s}\right)$

they influenced saturated conductivity less. The results imply that, as far as deep-seated failure (i.e. below rooting depth) is concerned, it may be unconservative simply to use the fallow soil saturated conductivity in slope stability calculations (i.e. to assume that root growth has a negligible effect during early tree establishment).

Willow had larger effects on suction redistribution than grass after 8 days of drainage (Fig. 6). Root growth-induced increase in saturated conductivity caused greater suction recovery in surface horizons. This means that the ability of plants to create soil water deficit is underestimated when the plant age effects are ignored. Although greater suction recovery is beneficial to slope stability, for other applications such as landfill cover design, ignoring root age effects could degrade the accuracy of soil water balance calculations.

\section{SUMMARY AND CONCLUSIONS}

This study quantified the effects of roots and their growth for two distinct plant functional types (grass and willow) on water infiltration rate during early plant establishment. Root growth induced an increase in infiltration rate by up 
Table 4. Summary of input parameters for seepage analysis

\begin{tabular}{|c|c|c|c|c|c|c|}
\hline \multirow[t]{2}{*}{ Treatment } & \multirow[t]{2}{*}{ Rooting depth: $\mathrm{m}$} & \multicolumn{5}{|c|}{ Hydraulic properties for van Genuchten (1980) model* } \\
\hline & & $\alpha: \mathrm{kPa}^{-1}$ & $n$ & $\theta_{\mathrm{r}}$ & $\theta_{\mathrm{s}}$ & $k_{\mathrm{s}}: \mathrm{m} / \mathrm{s}$ \\
\hline $\begin{array}{l}\text { Fallow } \\
2 \text { week willow } \\
4 \text { week willow } \\
6 \text { week willow } \\
8 \text { week willow } \\
2 \text { week grass } \\
4 \text { week grass } \\
6 \text { week grass } \\
8 \text { week grass }\end{array}$ & $\begin{array}{l}\text { N/A } \\
0 \cdot 256 \\
0.450 \\
0.630 \\
0.800 \\
0 \cdot 172 \\
0 \cdot 367 \\
0 \cdot 450 \\
0.500\end{array}$ & $0 \cdot 15$ & $1 \cdot 43$ & $0 \cdot 170$ & $0 \cdot 383$ & $\begin{array}{l}2 \cdot 16 \times 10^{-6} \\
5 \cdot 03 \times 10^{-6} \\
9 \cdot 95 \times 10^{-6} \\
1 \cdot 74 \times 10^{-5} \\
2 \cdot 56 \times 10^{-5} \\
2 \cdot 16 \times 10^{-6} \\
6 \cdot 13 \times 10^{-6} \\
7 \cdot 64 \times 10^{-6} \\
1 \cdot 32 \times 10^{-5}\end{array}$ \\
\hline
\end{tabular}

*Note: The fitting parameters, $\alpha, n, \theta_{\mathrm{r}}$ and $\theta_{\mathrm{s}}$ are obtained from Liang et al. (2017).

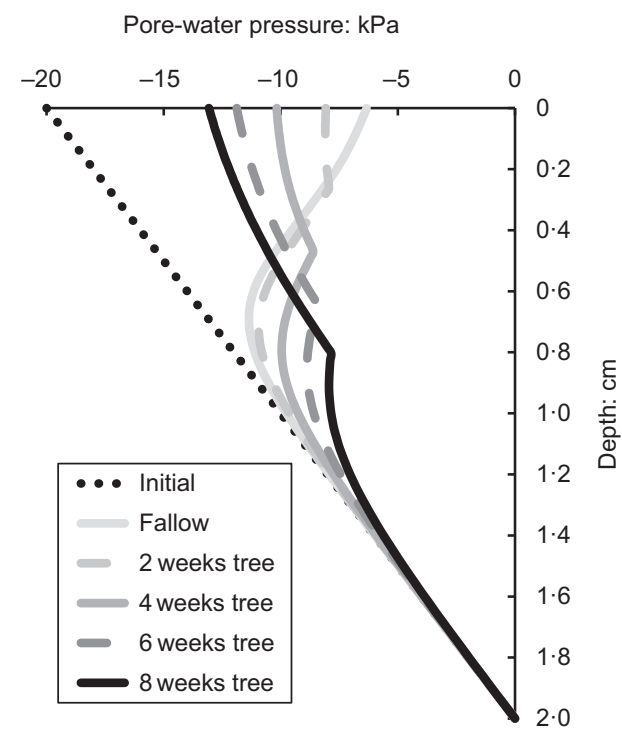

(a)

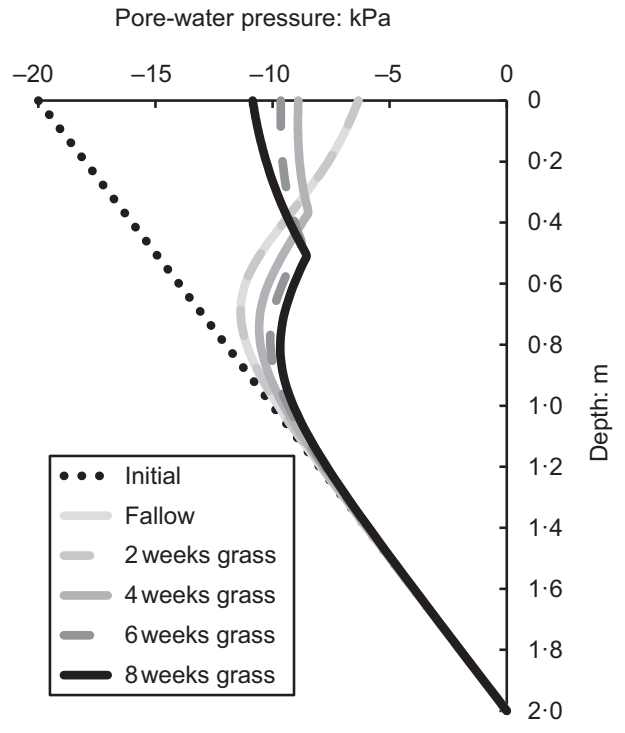

(b)

Fig. 5. Simulated pore-water pressure profiles at different plant ages after 2 days of rainfall when soil is vegetated with (a) the willow and (b) the grass

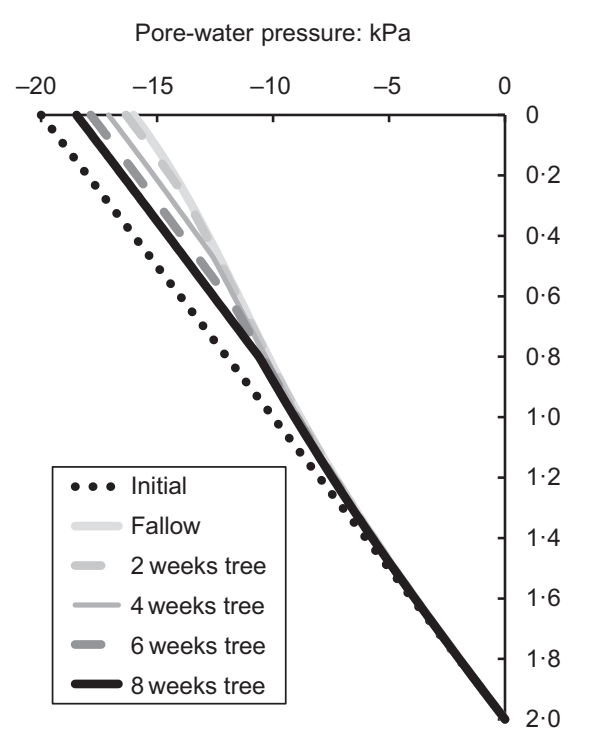

(a)

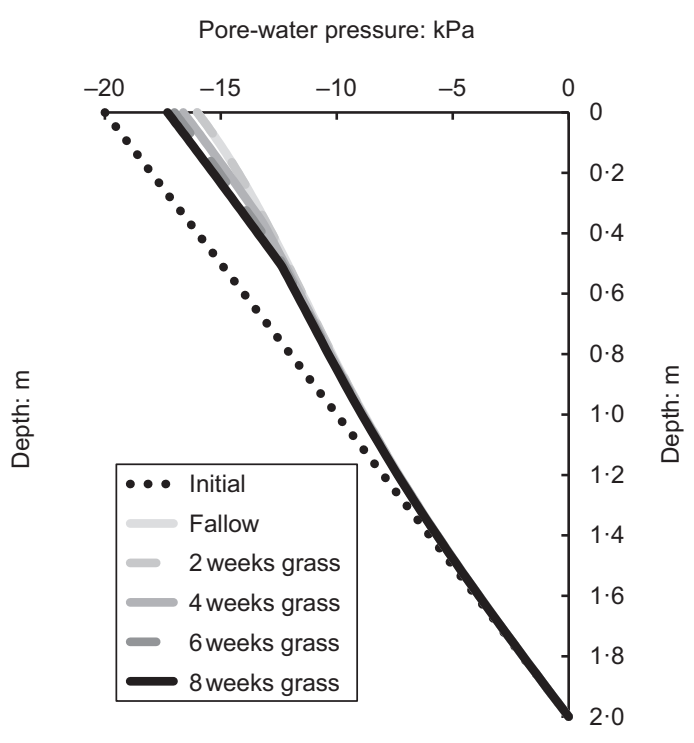

(b)

Fig. 6. Simulated pore-water pressure profiles at different plant ages after 8 days of internal drainage when soil is vegetated with (a) the willow and (b) the grass 
to an order of magnitude, compared to fallow soil. The root age effect was more prominent for willow, which grew faster and had thicker roots than grass. A positive correlation was identified between infiltration rate and plant age. Below-ground plant traits including root biomass and root length density could explain the infiltration rate for individual species. Illustrative seepage analysis suggests that ignoring the plant root and its age effects on soil hydraulic conductivity could underestimate wetting front advancement to depth during rainfall, and underestimate suction recovery at shallow depths during internal drainage. Compared to grass roots, willow roots introduced more significant changes in soil hydrology at this early growth stage.

\section{ACKNOWLEDGEMENTS}

Funding is acknowledged from EU FP 7 Marie Curie Career Integration grant (project BioEPIC slope; AKL and $\mathrm{DB})$; the Engineering and Physical Sciences Research Council (EPSRC) grant EP/M019713/1 (AGB and TL); the Chinese Scholarship Council (ZW) and the Hong Kong/ Scotland Partners of Post-Doctoral Research grant (S-HKUST601/15; VK). The James Hutton Institute receives funding from the Scottish government. Thanks to Professor Mike Humphreys (IBERS, Aberystwyth University) for providing grass seed for this study.

$\begin{aligned} & \text { NOTATION } \\ & g \text { root growth coefficient } \\ & k_{\mathrm{s}} \text { hydraulic conductivity at saturation } \\ & L_{\mathrm{m}} \text { maximum rooting depth } \\ & L_{\mathrm{R}} \text { rooting depth at time } t \\ & L_{0} \text { initial rooting depth } \\ & m, y_{0} \text { fitting coefficients } \\ & t \text { growing period } \\ & \alpha, n, \theta_{\mathrm{r}}, \theta_{\mathrm{s}} \text { fitting parameters }\end{aligned}$

\section{REFERENCES}

Archer, N. A. L., Otten, W., Schmidt, S., Bengough, A. G., Shah, N. \& Bonell, M. (2015). Rainfall infiltration and soil hydrological characteristics below ancient forest, planted forest and grassland in a temperate northern climate. Ecohydrol. 9, No. 4, 585-600.

Bodner, G., Leitner, D. \& Kaul, H. P. (2014). Coarse and fine root plants affect pore size distributions differently. Plant Soil 380, No. $1,133-151$.

Boldrin, D., Leung, A. K. \& Bengough, A. G. (2017). Correlating hydrologic reinforcement of vegetated soil with plant traits during establishment of woody perennials. Plant Soil 416, No. $1-2,437-451$.

Elci, A. \& Molz, F. J. (2009). Identification of lateral macropore flow in a forested riparian wetland through numerical simulation of a subsurface tracer experiment. Water Air Soil Pollut. 197, No. 1-4, 149-164.

Ghestem, M., Sidle, R. C. \& Stokes, A. (2011). The influence of plant root systems on subsurface flow: implications for slope stability. Bio Science 61, No. 11, 869-879.

Gish, T. J. \& Jury, W. A. (1983). Effect of plant roots and root channels on solute transport. Trans. Am. Soc. Agric. Biol. Engng 26, No. 2, 440-444

Jotisankasa, A. \& Sirirattanachat, T. (2017). Effects of grass roots on soil-water retention curve and permeability function. Can. Geotech. J 54, No. 11, 1612-1622.

Leung, A. K., Garg, A., Coo, J. L., Ng, C. W. W. \& Hau, B. C. H. (2015). Effects of roots of Cynodon dactylon and Schefflera heptaphylla on water infiltration rate and soil hydraulic conductivity. Hydrol. Process. 29, No. 15, 3342-3354.

Liang, T., Bengough, A. G., Knappett, J. A., Muir Wood, D., Loades, K. W., Hallett, P. D., Boldrin, D., Leung, A. K. \& Meijer, G. J. (2017). Scaling of the reinforcement of soil slopes by living plants in a geotechnical centrifuge. Ecol. Engng, https://doi.org/10.1018/j.ecoleng.2017.06.067.

Macleod, C. J. A., Humphreys, M. W., Whalley, W. R., Turner, L., Binley, A., Watts, C. W., Skot, L., Joynes, A., Hawkins, S., King, I. P., O’Donovan, S. \& Haygarth, P. M. (2013). A novel grass hybrid to reduce flood generation in temperate regions. Sci. Rep. 3, article 1683.

Mickovski, S. B., Hallett, P. D., Bransby, M. F., Davies, M. C. R., Sonnenberg, R. \& Bengough, A. G. (2009). Mechanical reinforcement of soil by willow roots: impacts of root properties and root failure mechanism. Soil Sci. Soc. Am. J. 73, No. 4, 1276-1285.

Mitchell, A. R., Ellsworth, T. R. \& Meek, B. D. (1995). Effect of root systems on preferential flow in swelling soil. Communs Soil Sci. Plant Analysis 26, No. 15-16, 2655-2666.

Ng, C. W. W., Ni, J. J., Leung, A. K. \& Wang, Z. J. (2016). A new and simple water retention model for root-permeated soils. Géotechnique Lett. 6, No. 1, 106-111, https://doi.org.10.1680/ jgele.15.00187.

Ng, C. W. W., Ni, J. J., Leung, A. K., Zhou, C. \& Wang, Z. J. (2017). Effects of planting density on tree growth and induced suction. Géotechnique 66, No. 9, 711-724, https://doi.org/10.1680/jgeot. 15.P.196.

Nyambayo, V. \& Potts, D. M. (2010). Numerical simulation of evapotranspiration using a root water uptake model. Comput. Geotech. 37, No. 1-2, 175-186.

Schmidt, K. M., Roering, J. J., Stock, J. D., Dietrich, W. E., Montgomery, D. R. \& Schaub, T. (2001). The variability of root cohesion as an influence on shallow landslide susceptibility in the Oregon Coast Range. Can. Geotech. J. 38, No. 5, 995-1024.

Scholl, P., Leitner, D., Kammerer, G., Lioskandl, W., Kaul, H. P. \& Bodner, G. (2014). Root induced changes of effective 1D hydraulic properties in a soil column. Plant Soil 381, No. 1-2, 193-213.

Sidle, R. C. \& Bogaard, T. A. (2016). Dynamic earth system and ecological controls of rainfall-initiated landslides. Earth-Sci. Rev. 159, 275-291.

Šimůnek, J. \& Suarez, D. L. (1993). Modelling of carbon dioxide transport and production in soil: 1 . Model development. Water Resources Res. 29, No. 2, 487-497.

Šimůnek, J., Sejna, H., Saito, M. \& van Genuchten, M. T. (2013). The HYDRUS-1D software package for simulating the one-dimensional movement of water, heat and multiple solutes in variably-saturated media. Riverside, CA, USA: Department of Environmental Sciences, University of California Riverside.

Song, L., Li, J. H., Zhou, T. \& Fredlund, D. G. (2017). Experimental study on unsaturated hydraulic properties of vegetated soil. Ecol. Engng 103, Part A, 207-216.

Steele, D., MacNeil, D., Barker, D. \& McMahon, W. (2004). The use of live willow piles for stabilising highway slopes, TRL Report No. 619, 685. Crowthorne, UK: Transport Research Laboratory.

Stokes, A., Douglas, G. B., Fourcaud, T., Giadrossich, F., Gillies, C., Hubble, T., Kim, J. H., Loades, K. W., Mao, Z., McIvor, I. R., Mickovski, S. B., Mitchell, S., Osman, N., Phillips, C., Poesen, J., Polster, D., Preti, F., Raymond, P., Rey, F., Schwarz, M. \& Walker, L. R. (2014). Ecological mitigation of hillslope instability: ten key issues facing researchers and practitioners. Plant Soil 377, No. 1-2, 1-23.

Tsiampousi, A., Zdravkovic, L. \& Potts, D. M. (2017). Numerical study of the effects of soil-atmosphere interaction on the stability and serviceability of cut slopes in London clay. Can. Geotech. J. 54, No. 3, 405-418.

van Genuchten, M. T. (1980). Closed-form equation for predicting the hydraulic conductivity of unsaturated soils. Soil Sci. Soc. Am. J. 44, No. 5, 892-898.

van Noordwijk, M., Widianto, H. M. \& Hairah, K. (1991). Old tree root channels in acid soils in the humid tropics: Important for crop root penetration, water infiltration and nitrogen management. Dev. Plant Soil Sci. 134, No. 1, 37-44.

Vergani, C. \& Graf, F. (2015). Soil permeability, aggregate stability and root growth: a pot experiment from a soil bioengineering perspective. Ecohydrol. 9, No. 5, 830-842.

Wu, T., Kokesh, C., Trenner, B. \& Fox, P. (2014). Use of live poles for stabilisation of a shallow slope failure. J. Geotech. Geoenviron. Engng 140, No. 10, paper 05014001.

Zhan, T. L. T., Ng, C. W. W. \& Fredlund, F. G. (2007). Field study of rainfall infiltration into a grassed unsaturated expansive soil slope. Can. Geotech. J. 44, No. 4, 392-408. 